\title{
PENDIDIKAN KEDAMAIAN DI ERA DIGITAL (TELAAH MODEL FORGIVENESS DALAM PSIKOLOGI ISLAM)
}

\author{
Fitriah M. Suud \\ Universitas Muhammadiyah Yogyakarta \\ fitriahmsuud@gmail.com
}

\begin{abstract}
The effort to make Islam a discipline is a necessity, because the sources of knowledge in Islam are infinite. The emerging problem usually does not lie in the matter (ontological) and its value (axiological), but on the matter of how the material is presented scientifically (epistimologically) and how a normative matter is grounded to the point that it can be used by many people. Responding to the changing times of the industry revolutionized 4.0 and in this digital era where many of life's problems increasingly complex. Fights, strife, stress, and the level of frustration increases everywhere. It is demand an educational movement to return to the teachings of Islam rahmatan lil alamin. The aims of this paper are to concoct a famous science material in Islam and has become a topic in positive psychology that is forgiveness as an attempt to become a reflection and practice of reconciling the soul in the digital era. Looking back at the teachings of Islam that are full of the value of peace and compassion for the whole of nature which is a manifestation of the nature of forgiveness or forgiveness. This study is qualitative and uses idealistic methods from Islamic psychology disciplines.
\end{abstract}

Keywords: Concept of Forgiveness; Islam; Positive Psychology; Digital era.

\begin{abstract}
Abstrak
Upaya menjadikan Islam sebagai disiplin ilmu merupakan suatu keniscayaan, sebab sumber-sumber pengetahuan dalam Islam tak terhingga banyaknya. Problem yang mengemuka biasanya bukan terletak pada materi (ontologis) dan nilanya (aksiologis), melainkan pada masalah bagaimana materi itu disuguhkan secara ilmiah (epistimologis) serta bagaimana sebuah hal normative membumi hingga dapat dengan nyata digunakan oleh banyak orang. Menanggapi perubahan zaman direvolusi industri 4.0 dan di era digital ini dimana banyak persoalan kehidupan semakin komplek. Perkelahian dan pertikaian dimana-mana serta tingkat frustasi meningkat, tingkat stress semakin naik di kalangan para pelajar, maka perlu sebuah gerakan pendidikan untuk kembali kepada ajaran Islam yang rahmatan lil alamin. Tujuan dari tulisan ini adalah meramu sebuah materi ilmu
\end{abstract}


yang terkenal dalam Islam dan telah menjadi topik dalam psikologi positif yaitu forgiveness sebagai sebuah upaya untuk menjadi renungan dan praktek mendamaikan jiwa di era digital. Melihat kembali ajaran Islam yang sarat dengan nilai perdamaian dan kasih sayang untuk seluruh alam yang merupakan manifestasi dari sifat forgiveness atau kemaafan. Kajian ini bersifat kualitatif dan memakai metode idealistik dari disiplin ilmu psikologi Islam.

Keywords: Konsep Forgiveness; Islam; Psikologi Positif; Era digital.

\section{Pendahuluan}

Era digital merupakan era yang telah mengubah banyak hal kehidupan dalam berbagai sisi. Setiap perubahan zaman pasti membawa dua hal yang seimbang. Keduanya adalah hal positif dan hal yang negatif. Kemudahan untuk berkomunikasi laju arus informasi tak terbendung terjadi lintas negara, agama dan budaya. Seakan dunia menjadi sempit dan tak lagi berjarak untuk sebuah informasi. Hal ini dapat dimanfaatkan untuk dunia Pendidikan yang tentu saja membutuhkan banyak informasi dalam proses peningkatan pengetahuan. Seorang pendidik dapat mengakses banyak pengetahuan yang telah terjadi di belahan dunia lain, begitu juga dengan pelajar dapat melihat hasil penelitian para pakar di seluruh dunia dengan sangat mudah sehingga menjadi khazanah tersendiri untuk membuka cakrawala berfikir.

Kondisi di atas menunjukkan bahwa perkembangan di era digital memberikan efek yang positif untuk perkembangan ilmu pengetahuan umat. Dalam hal lain pun dapat dimanfaatkan sistem informasi yang serba mudah. Seseorang tidak lagi perlu menghabiskan banyak kertas untuk menulis dan menyimpan dokumennya dalam bentuk paper. Sehingga zaman ini pun kemudian dikenal dengan zaman peperless. Guru, dengan memanfaatkan kecanggihan alat digital tidak perlu lagi mencetak pengumuman untuk dibagikan kepada seluruh orang. Pengumuman dapat ditulis sekali di selulernya yang digital lalu mengirimnya hanya dengan sekali sentuh terkirim kesemua informasi wali murid melalui aplikasi whatsApp. Sangat mudah, murah dan sangat membantu. Berbagai kemudahan yang ditemukan pada zaman digital ini, memberikan kebermanfaatan untuk banyak orang terutama dalam dunia pendidikan yaitu untuk Pendidik dan para pelajar di berbagai sekolah.

Dibalik kebermanfaatan yang luar biasa itupun pasti memiliki hal negatif yang perlu diwaspadai. Dengan mudahnya informasi terkirim melalui sentuhan jemari para pengguna banyak malapetaka pun terjadi. Tidak sedikit perkelahian terjadi yang 
berawal dari informasi yang salah di dunia maya. Banyak pasangan berpisah karena membaca pesan yang diteruskan oleh pihak lain ke handphonenya. Model copy paste terjadi dengan mudah dan telah menjadi hal yang sangat bisa. Orang bisa mengatasnamakan orang lain untuk mengirim pesan, pesan hoaxpun kemudian tak terbentuk. Screen short merebak, rahasia terbongkar adu domba, hujatan caci-maki dan kebencian mudah terjadi. Alhasil muncul was-was dan kurang percaya pada rekan sendiri. Selain krisis kepercayaan juga muncul kegelisahan dan mengusik kedamaian dan ketenangan hidup.

Islam sebagai agama rahmatan lil 'alamin dengan al-Qurán sebagai hudan yang berlaku sepanjang zaman memberikan solusi untuk kehidupan yang layak dan rukun serta berada dalam kedamaian. Salah satu ajaran Islam adalah memaafkan. Konsep maaf ini ternyata memiliki implikasi yang sangat besar untuk kehidupan umat. Sehingga kemaafan menjadi sebuah topik sendiri yang masuk dalam ranah psikologi positif yang merupakan aliran psikologi yang terhitung baru dalam perkembangan ilmu psikologi. Lahirnya psikologi ini membawa angin segar bagi perkembangan psikologi Barat yang telah menghabiskan waktunya membahas persoalan negatif, seputar pathologi yang dimiliki oleh manusia. Psikologi Positif menawarkan cara baru untuk melihat manusia tidak lagi fokus pada mengobati sakit dan melihat kekurangan seseorang tetapi beranjak dengan melihat potensi dan kekuatan yang dimiliki oleh individu.

Pemaafan selanjutnya secara langsung mempengaruhi ketahanan dan kesehatan fisik dengan mengurangi tingkat permusuhan, meningkatkan sistem kekebalan pada sel dan neuro-endokrin, membebaskan antibodi, dan mempengaruhi proses dalam sistem saraf pusat ${ }^{1}$. Beberapa tokoh yang memberikan perhatiannya pada teori forgiveness adalah Thomson, McCullough, Enright, dan Tangney. ${ }^{2}$ Semua tokoh ini memiliki definisi tersendiri terhadap forgiveness. McCullough mendefinisikan forgiveness sebagai sebuah rangkaian perubahan motivasi yaitu dari motivasi balas dendam menjadi

\footnotetext{
${ }^{1}$ Worthington, E. L., \& Scherer, M.. Forgiveness is an Emotion-Focused Coping Strategy That Can Reduce Health Risks And Promote Health Resilience: Theory, Review, And Hypotheses. Psychology \& Health, 19. 3. 2004), 385-405.

${ }^{2}$ Snyder, C. R., \& Lopez, S. J. (2009). Oxford handbook of positive psychology. Oxford University Press, USA.
} 
menurun, motivasi menghindari bertemu dengan pelaku menurun dan motivasi berlaku damai menjadi meningkat. ${ }^{3}$

Thompson dalam C.R. Snyder el. at. (2011) mendefinisikan pemaafan sebagai upaya untuk menempatkan peristiwa pelanggaran yang dirasakan oleh seseorang, respon seseorang terhadap pelaku, peristiwa, dan akibat dari peristiwa yang dialami diubah dari negatif menjadi netral atau positif. Forgiveness dapat terjadi pada tiga hal yaitu kemaafan untuk orang lain, diri sendiri dan untuk kondisiyaitu memaafkan situasi yang menyebabkan munculnya perasaan negatif dalam dirinya misalkan bencana dan lainlain. Enright (2002), mengatakan forgiveness adalah kesediaan seseorang untuk meninggalkan kemarahan dan penilaian negatif terhadap orang yang telah menyakitinya. Membalasnya dengan kasih sayang dan cinta serta kemurahan hati. ${ }^{4}$

Islam mengajarkan kemaafan bagi para pemeluknya ${ }^{5}$. Kemaafan untuk dirinya, untuk sesama bahkan kemaafan bagi seluruh makhluk ciptaan Tuhan termasuk hewan dan tumbuhan sekalipun. Hingga terlihat bahwa makna dan jangkauan teori kemaafan dalam Islam lebih luas dibandingkan dengan teori forgiveness dalam psikologi Barat. Allah menyebutkan diriNya sebagai ghaffar dalam 99 nama-nama Allah yang indah dalam Asmaul Husna yang bearti Maha memaafkan. Ini memberikan arti bahwa Islam adalah agama dengan ajaran kemaafan yang sangat kental di mana pemeluknya dapat melihat dari nama indah yang dimiliki oleh Tuhannya. Tulisan ini diharapkan dapat menjadikan forgiveness sebagai sebuah khazanah ilmu dalam Islam yang membumi dan dapat dipraktekkan di era digital saat ini.

\section{Tujuan dan Metode pembahasan}

Secara keseluruhan tujuan dari tulisan ini adalah memberikan salah satu pandangan Islam untuk menanggapi perubahan zaman umat agar umat tetap tenang dan hidup rukun di era digital serta era revolusi industri keempat ini. Sementara metode tulisan ini adalah bersifat kualitatif dengan pendekatan Studi Pustaka. Metode kualitatif adalah prosedur penelitian yang menghasilkan data deskriptif berupa kata-kata tertulis

\footnotetext{
${ }^{3}$ McCullough, M. E., \& Witvliet, C. V. (2002). The psychology of forgiveness. Handbook of positive psychology, 2, 446-455.

${ }^{4}$ Freedman, S., Enright, R. D., \& Knutson, J. A Progress Report On The Process Model Of Forgiveness. (Handbook of forgiveness. 2005)., 393-406.

${ }^{5}$ Dalam Islam ajaran tentang memberikan kemaafan dan memohon maaf banyak terdapat dalam al-Qurán. Hal tersebut dapat ditemukan dalam beberapa ayat al-Qurán di antaranya adalah: surah al-Baqarah ayat 237, al-Baqarah ayat 286, Ali Imran ayat 133-134, asyura 33-34, asyura ayat 39-44, dan banyak lainnya. Selain itu kajian konsep kemaafan juga dibahas oleh para tokoh Islam seperti imam Al-Ghazali.
} 
atau lisan dari orang-orang dan perilaku yang dapat diamati didukung dengan studi literatur atau studi kepustakaan berdasarkan pendalaman kajian pustaka berupa data dan angka, sehingga realitas dapat dipahami. ${ }^{6}$ Selanjutnya karena studi ini adalah sebuah kajian psikologi Islam maka tulisan ini akan memakai pola idealistik yaitu dengan mereduksi ayat-ayat al-Qur'an dan sumber lain yang mendukung untuk penelitian ini. ${ }^{7}$ Selanjutnya melihat bagaimana kemaafan dalam literature psikologi positif sebagai ilmu yang telah diempiriskan dengan skala tertentu.

Tujuan dan solusi dari permasalahan dapat diberikan setelah adanya penyajian konsep kemaafan dalam Islam secara normatif dan menilik kajian kemaafan melalui kajian empiris dalam pskologi positif. Kajian normatrif dalam Islam dicari melalui kajian al-Qurán, hadits, pendapat para tokoh dalam hal ini pendapat Imam al-Ghazali dan Quraish Shihab. Secara empiris penulis melihat bagaimana kemaafan secara empiris dilakukan oleh para psikolog dalam kajian ilmu psiklogi posisitif. Setelah melihat bagaimana pandangan Islam dan pandangan psikologi positif maka akan ditemukan solutif untuk berbagai persoalan di lapangan yaitu kegelisahan akademik penulis yaitu tingkat perkelahian yang tinggi, stress dan tingkat frustasi yang semakin meningkat. Bentuk solusif yang dimaksud diberikan dalam bentuk pendidikan kedamaian. Untuk lebih jelasnya desain pembahasan tulisan ini dijelaskan dalam bab desain penelitian.

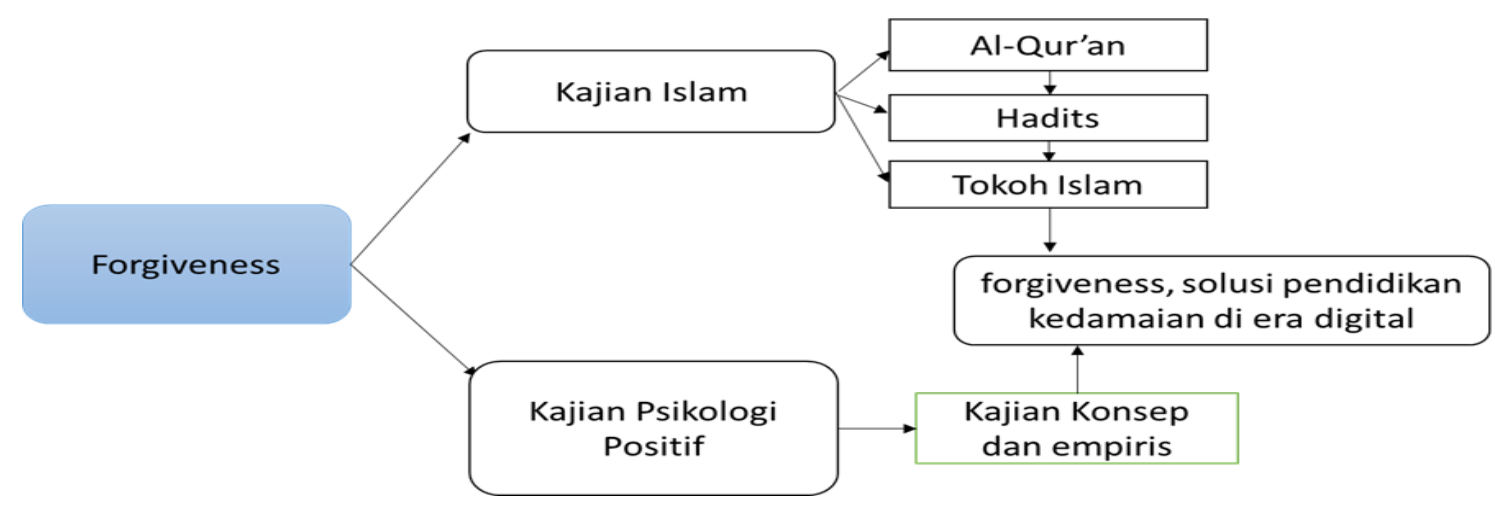

\section{Gambar 1: Desain penelitian dan pembahasan}

\footnotetext{
${ }^{6}$ Moleong, L.J. 1996. Metodologi Penelitian Kualitatif. Bandung: Penerbit PT. Remaja Rosdakarya,3.

${ }^{7}$ Mujib, A. (2017). Pengembangan Psikologi Islam Melalui Pendekatan Studi Islam. Jurnal Psikologi Islam.
} 
Fitriah M. Suud, Pendidikan Kedamaian di Era Digital, Telaah Model Forgiveness dalam Psikologi Islam

\section{Pengertian Forgiveness dalam Islam}

Untuk memberikan gambaran awal dari studi ini maka akan dimulai dari penjelasan makna dari forgiveness dalam Islam. Forgiveness dalam bahasa Indonesia identik dengan kata maaf dan kata maaf dalam bahasa al-Qur'an terdapat dalam kata al'awf dan ghaffara. Kata al-'afw, terambil dari akar kata yang terdiri dari huruf-huruf ain, fa dan wauw. Maknanya berkisar pada dua hal, yaitu meninggalkan sesuatu dan memintanya. Secara bahasa kata 'afw memiliki dua makna dasar, yakni tarku asy syai (meninggalkan Sesuatu) dan Thalabu asy Syai (meminta Sesuatu). ${ }^{8}$ Dari sini lahir 'afw, yang berarti meninggalkan sanksi atau hukuman dan balasan terhadap yang bersalah atau memberikan kemaafan.

Selanjutnya perlindungan Allah swt dari keburukan juga dinamai 'Afiat. Perlindungan mengandung makna ketertutupan. Dari sini, kata 'afw juga diartikan menutupi, bahkan dari rangkaian ketiga huruf itu juga lahir makna terhapus atau habis tiada berbekas, karena yang terhapus dan habis tidak berbekas pasti ditinggalkan. Selanjutnya al-'afw dapat juga bermakna kelebihan, karena yang berlebih seharusnya tidak ada dan harus ditinggalkan, yakni dengan memberi siapa yang memintanya. Dalam beberapa kamus dinyatakan bahwa pada dasarnya kata 'afw, berarti menghapus dan membinasakan serta mencabut akar sesuatu. ${ }^{9}$ Sehingga yang dimaksud dengan $a l$ 'afw di sini adalah berlapang dada dalam memberikan maaf kepada orang lain yang telah melakukan kesalahan, tanpa disertai rasa benci di hati.

\section{Forgiveness dalam Al-Qur'an dan Hadits}

Al-Qur'an sebagai sumber utama ajaran Islam mengulang kata al-'Afw sebanyak tiga puluh lima kali dalam berbagai bentuk dan makna. ${ }^{10}$ Ini juga merupakan isyarat bahwa kemaafan merupakan salah satu teori yang kuat dalam Islam. Beranjak pada sumber hukum Islam yang kedua yaitu Hadits maka ditemukan kata maaf digunakan oleh setiap para perawi hadits kutubustis'ah. Demikian juga dengan kehidupan Rasululah saw sendiri yang diakui kebaikan dan tingkat kemaafannya bukan hanya oleh

\footnotetext{
${ }^{8}$ Quraish Shihab, Wawasan Al-Qur"an (Bandung: Mizan, 1998), Cet VIII, 248-250.

${ }^{9}$ M. Quraish Shihab, Menyingkap Tabir Ilahi, (Jakarta: Penerbit Lentera Hati , 2004), Cet III, 364.

${ }^{10}$ Kata-kata tersebut dapat ditemukan dalam al-Qurán surah al-Baqarah ayat 237, 263, 286, Ali Imran ayat 133-134, asyura ayat 33-34, 39-40, An-Nisa ayat 49, an-Nur ayat 22, al-Buruj ayat 14, al-anfal ayat 33, Hud ayat 3, dan an-Naml ayat 46. Muhammad Fuas Ábdul Baqi, Mu’jam Mufahras li Alfazh Al-Qurán alKarim, (al:Qahirah: Dar al Hadits, 2007), 572,
} 
umat Islam tetapi juga diakui oleh kaum kafir Quraiys. Ini adalah sebagian dari isyarat dan pertanda bahwa Islam menawarkan teori kemaafan yang bukan hanya sekedar teori tetapi juga telah dipraktekan. Bukan hanya di perintahkan kepada pemeluk agamanya, Nabinya namun Allah swt pun memiliki nama sebagai yang Maha Memaafkan.

Al-Qur'an dan Hadits memberikan kriteria dan beberapa jenis kemaafan. Yang pertama adalah maafnya Allah kepada hambaNya. Dan kemaafan ini bukan hanya diberikan kepada manusia yang telah meminta ampunan, melainkan juga diberikan tanpa didahului oleh permintaan maaf atau ampunan. Hal ini dapat dilihat dari surah asy-syura ayat 33-34:

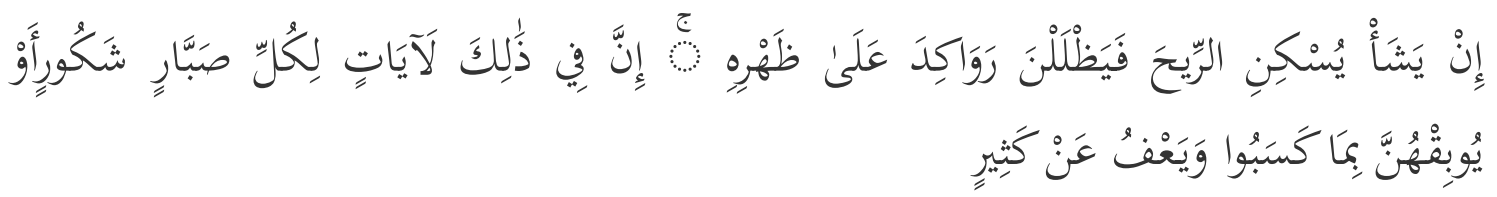

Artinya: Jika Dia menghendaki, Dia akan menenangkan angin, maka jadilah kapalkapal itu terhenti di permukaan laut. Sesungguhnya pada yang demikian itu terdapat tanda-tanda (kekuasaannya) bagi setiap orang yang banyak bersabar dan banyak bersyukur, atau kapal-kapal itu dibinasakan-Nya karena perbuatan mereka atau Dia memberi maaf sebagian besar (dari mereka). (Q.S: Asy-Syura ayat 33-34)

Ayat di atas menjelaskan bahwa memberi maaf kepada seseorang tidak harus karena telah dimohon untuk dimaafkan. Akan tetapi sesama manusia harus saling memaafkan. Ayat di atas adalah sebuah pembelajaran dan ibrah untuk manusia dalam mengimplementasikan kemaafannya. Selanjutnya al-Qur'an juga memberikan isyarat yang kedua yaitu kemaafan oleh manusia. Kemaafan pada manusia ini dapat dilihat dari tiga tipe: 1) kemaafan sebagai sebuah sikap. Maksudnya bahwa kemaafan ini bukanlah sebuah kewajiban di dalam Islam karena seseorang dapat membalas perbuatan yang setimpal sesuai hukum yang telah ditetapkan. Namun ketika seseorang memilh untuk tidak membalas tetapi malah memaafkan ini adalah pilihan bagi seseorang. Hal ini menunjukkan bahwa kemaafan dalam Islam bukan menunjukkan kelemahan melainkan menunjukkan sebuah kemuliaan. Mengenai hal ini al-Qur'an menyebutkannya dalam surah Asy Syura ayat 39-40:

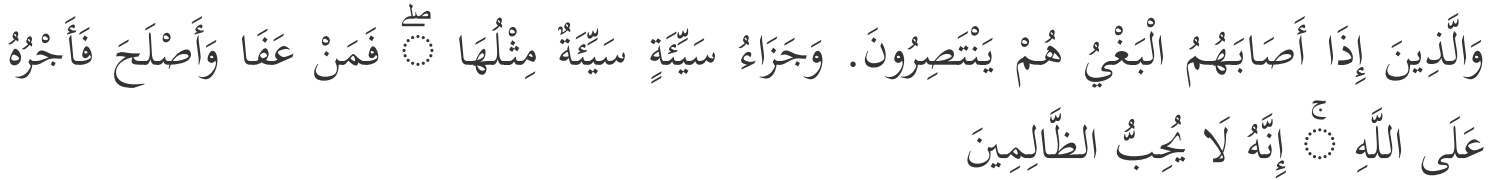


Artinya: Dan (bagi) orang-orang yang apabila mereka diperlakukan dengan zalim mereka membela diri. Dan balasan suatu kejahatan adalah kejahatan yang serupa, maka barang siapa memaafkan dan berbuat baik maka pahalanya atas (tanggungan) Allah. Sesungguhnya Dia tidak menyukai orang-orang yang zalim. (Q.S; Asy Syura ayat 39-40)

Ayat ini menjelaskan bahwa pilihan sikap memaafkan oleh seseorang adalah lebih baik dari pada membalasnya meskipun ia dapat melakukannya. Dan karena pilihannya untuk memaafkan kesalahan insan yang lain maka Allah memberikan kebaikan (pahala) yang pasti kepada mereka yang memilih jalan bersikap mulia dengan memberikan maaf kepada pelaku yang telah berbuat buruk padanya. 2) kemaafan sebagai sebuah sifat. Untuk melihat kemaafan sebagai sebuah sifat yang mulia dalam Islam maka rujukannya adalah sifat yang dimiliki oleh Rasulullah. Sebagai pemberi contoh suri tauladan kepada seluruh umat manusia di dunia ini, siapa saja dapat melihat jejak perjalanan hidupnya pada hadits yang di tinggalkan. Di antara hadits tentang sifat kemaafan adalah sebagai berikut:

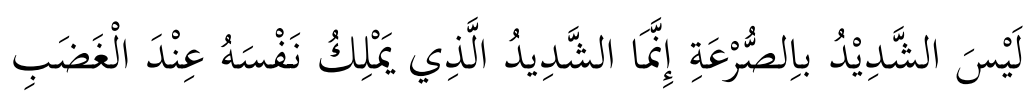

Artinya: "Orang yang kuat bukan yang banyak mengalahkan orang dengan kekuatannya. Orang yang kuat hanyalah yang mampu menahan dirinya di saat marah." (HR. Al-Bukhari no. 6114).

Memperhatikan hadits di atas mencerminkan sifat mulia para muslim yang dengan kekuataanya memilih untuk berlaku sabar menahan amarah dan tidak membalas dendam. Dalam banyak hadits lain juga diceritakan sifat Rasulullah yang tidak membalas dendam meskipun kepada mereka yang telah melemparnya dengan kotoran dan meludahinya setiapa kali Rasulullah ke Mesjid. ${ }^{11}$ Perbuatan semena-mena itu malah dibalas dengan menjenguknya ketika sakit. Demikian sifat kemuliaan yang dicontohkan Rasulullah saw dalam Islam.

Selain makna maaf dalam Islam yang bermula dari sifat Allah kepada manusia maka kata maaf juga terdapat pada sifat dan sikap manusia. 3) Pemaafan sebagai nilai moral. Artinya pemaafan perlu dilestarikan dan dibudayakan sehingga ia dapat muncul setiap waktu. Karena persoalan yang menyinggung perasaan sering terjadi dalam kehidupan sehari-hari meskipun itu dengan keraabat, teman dan saudara sendiri, bahkan

\footnotetext{
${ }^{11}$ Abdul Mun ${ }^{e c i m ~ A l-H a s y i m i, ~ A k h l a k ~ R a s u l ~ M e n u r u t ~ B u k h a r i ~ d a n ~ M u s l i m ~(J a k a r t a: ~ G e m a ~ I n s a n i, ~ 2009), ~}$ Cet I, 357-358
} 
dengan pasangan hidup. Maka kemaafan sebagai moral ini dapat melanggengkan sebuah hubungan yang dibina. Sebagaimana yang dijelaskan dalam al-Qur'an surat ali Imran ayat 133-134.

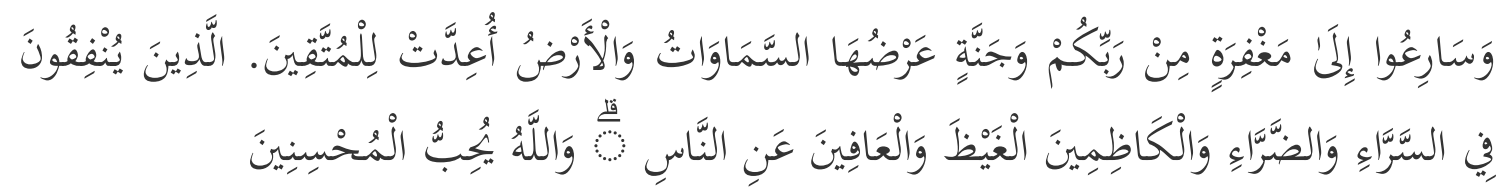

Artinya: Dan bersegeralah kamu kepada ampunan dari Tuhanmu dan kepada surga yang luasnya seluas langit dan bumi yang disediakan untuk orang-orang yang bertakwa. (yaitu) orang-orang yang menafkahkan (hartanya), baik di waktu lapang maupun sempit, dan orang-orang yang menahan amarahnya dan memaafkan (kesalahan) orang. Allah menyukai orang-orang yang berbuat kebajikan. (Q.S. Ali-Imran: 133-134)

Ayat ini menjelaskan agar manusia bersegera dalam berbuat kebaikan. Dan panggilan kebajikan dalam ayat di atas ditujukan kepada mereka yang bersedia menahan amarah dan berbuaut baik kepada orang yang telah buat jahat kepadanya. Tentu saja bukan hal yang mudah memaafkan dan ditambah dengan membalas rasa sakit dengan kebaikan-kebaikan sebagai balasannya. Namun Islam memberikan motivasi dan penguatan kepada pemeluknya agar yakin bahwa kebaikan yang dilakukannya bukanlah sesuatu yang sia-sia karena Allah yang menangung kebaikan dan kekuatan batinnya dalam mewujudkan niat baiknya memaafkan orang lain. Sementara kata maaf berikutnya juga dapat diambil dari kata ghaffar yang merupakan asal kata dari ghaffara yang berati menutup. Menutup di sini bermakna Allah menutupi dosa-dosa yang telah dilakukan oleh manusia karena sifat rahman dan rahim yang dimiliki oleh Allah. ${ }^{12}$

Kata awf dan ghaffar jika diperhatikan memiliki makna yang berbeda pada implementasinya. Perbedaan itu dapat dilihat pada surat al-Baqarah ayat 286. Pada surat ini kedua kata tersebut disandingkan dan tersirat penjelasannya kedua maknanya.

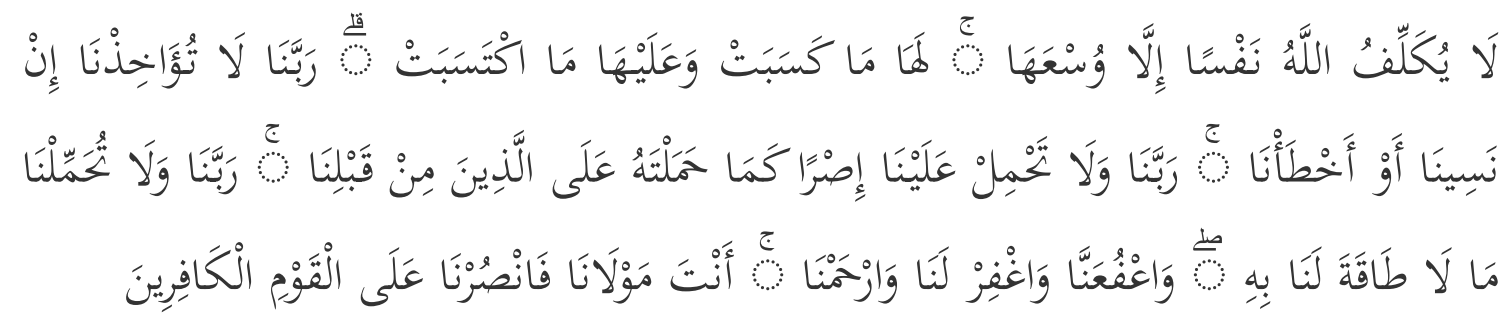

\footnotetext{
${ }^{12}$ Muhammad Syafie ${ }^{\text {ei }}$ Antonio, Asma"ul Husna For Success in Business \& Life (Jakarta: Tazkia Publishing, 2009), Cet III, 379
} 
Fitriah M. Suud, Pendidikan Kedamaian di Era Digital, Telaah Model Forgiveness dalam Psikologi Islam

Artinya: Allah tidak membebani seseorang melainkan sesuai dengan kesanggupannya. Ia mendapat pahala (dari kebajikan) yang diusahakannya dan ia mendapat siksa (dari kejahatan) yang dikerjakannya. (Mereka berdoa): "Ya Tuhan kami, janganlah Engkau hukum kami jika kami lupa atau kami tersalah. Ya Tuhan kami, janganlah Engkau bebankan kepada kami beban yang berat sebagaimana Engkau bebankan kepada orang-orang sebelum kami. Ya Tuhan kami, janganlah Engkau pikulkan kepada kami apa yang tak sanggup kami memikulnya. Beri maaflah kami; ampunilah kami; dan rahmatilah kami. Engkaulah Penolong kami, maka tolonglah kami terhadap kaum yang kafir". (Q.S. al-Baqarah: 286)

Ayat ini menjelaskan bahwa awf berarti memaafkan dan memaafkan berarti pelakunya tidak akan dibebani siksaan sebagai akibat dari perbuatannya dan dihapus semua nodanya, sedangankan al-Maghfirah berarti pelakunya tidak akan disiksa, teapi noda atau dosanya akan tetap ada dan belum terhapus dengan total. Sehingga apabila Allah memaafkan dosa hambaNya bearti Allah tidak akan menghukum hambaNya tersebut karena kesalahan yang telah dimaafkan tersebut. ${ }^{13}$ Oleh karena itu forgiveness bagi oleh manusia dalam perspektif lebih tepat menggunakan kata afw. Sementara kata ghaffara walaupun memiliki arti yang hampir sama namun kata ini lebih kepada hak ferogatif Tuhan dalam memberikan ampunan kepada hambaNya.

Melihat beberapa ayat dan hadits yang memuat makna maaf di atas dapat memberi isyarat akan ciri-ciri sifat dan sikap kemaafan ini dalam Islam. Yang pertama kemaafan dapat diberikan kepada siapa saja baik karena ia meminta mapun tanpa seseorang memohon maaf padanya dan yang ini lebih mulia derajatnya. Yang kedua kemaafan yang dilakukan dalam Islam ada dua yaitu kemaafan atau keampunan dari Tuhan kepada hambanya dan dari mahkluk kesesamanya. Kemaafan manusia untuk memohon ampun pada Allah atas segenap kesalahannya dan saling memaafkan dengan sesama manusia. Yang ketiga kemaafan dalam Islam bukan tanpa pamrih dan alasan melainkan dikuatkan dengan tanggungan kebajikan (pahala) dari Tuhannya. Sehingga ini menjadi sebuah sarana yang menguatkan umat untuk tetap bertahan dalam kebaikan.

\section{Forgiveness Menurut Tokoh Islam}

Bagian ini akan dibahas bagaimana pendapat para tokoh Islam dalam memandang konsep kemaafan dalam Islam. Penulis memilih dua tokoh besar dalam

\footnotetext{
${ }^{13}$ Cholidi, "Maghfirah,” 2008, dalam M. Quraish Shihab,et al. (ed.).Ensiklopedia al-Qur'an: Kajian Kosa Kata, vol. III. Jakarta: Lentera Hati.
} 
Islam yaitu Quraish Shihab dan Al-Ghazali dengan pertimbangan dua tokoh ini mewakili zaman klasik dan zaman kontemporer. Quraish Shihab merupakan salah seorang tokoh Islam yang dikenal dengan tafsir al-Mishbahnya dan juga banyk karyakarya lainnya yang sangat bannyak berbicara dengan nilai-nilai kebaikan dalam Islam. Salah satu kajiannya adalah persoalan kemaafan. Quraish Shihab memiliki beberapa pandangan atau makna tersendiri terhadap kemafan yaitu maaf memberi makna hilang tak berbekas. ${ }^{14}$ Selanjutnya juga bermakna berlebihan, seseorang yang memiliki kelebihan sehingga bisa memberikan kepada yang membutuhkan. ${ }^{15}$ Kedua makna ini dapat dianalisis bahwa kemaafan memiliki makna yang luas dan dalam.

Satu sisi, kemaafan berarti hilang tak bersisa, ini artinya bahwa seseorang yang memiliki kemaafan tidak menyisakan rasa kesal, rasa sakit apalagi dendam dalam hatinya. Seseorang yang memiliki siat kemaafan dapat menghilangkan keinginan untuk membalas dendam pada orang yang menyakitinya sehingga Qurais Shihab menyebutkan bahwa kemaafan bermakna hilang dan tiada bekas. Makna yang diberikan oleh Quraish Shihab perlu untuk ditegaskan bahwa hilang tak berbekas bukan bearti seseorang bisa melupakan setiap kejadian sakit yang telah dirasakan oleh seseorang melainkan yang dihilangkan tak berbekas itu adalah keinginan untuk membalas rasa sakit itu. ${ }^{16}$ Sehingga muncul kata-kata forgive but not forget karena otak manusia akan tetapi mengingat dan menyimpan semua memori dalam fikiran, apalagi memori yang aneh. Aneh artinya memiliki kesan tersendiri baik itu kejadian paling menyenangkan atau sebaliknya kejadian paling menyakitkan.

Makna berikutnya adalah lebih atau berlebihan. Secara sekilas kata-kata ini dapat memberikan arti ganda bisa berarti positif dan juga bisa berarti negatif. Sehinga perlu adanya penegasan bahwa kelebihan yang dimaksud di sini adalah memiliki makna positif yaitu seseorang yang memiliki kelebihan lalu karena memiliki banyak kelebihan ia memberikan kepada yang lain. Ini artinya bahwa kemaafan adalah kemampuan memberikan rasa aman dan rasa tidak bersalah kepada orang yang telah berbuat tidak menyenangkan. Dari dua hal tersebut dapat diambil kesimpulan bahwa perkara memaafkan bukan hal yang mudah. Sehingga barang siapa yang mampu memaafkan

\footnotetext{
${ }^{14}$ Quraish Shihab, Tafsir al-Misbah: Pesan, Kesan dan Keserasian Al-Qur'an, ( Jakarta: Lentera Hati, 2002), Vol 4, 427

${ }^{15}$ Ibid.

${ }^{16}$ Quraish Shihab, Membumikan al-Qur'an: Fungsi dan Peran Wahyu dalam Kehidupan Masyarakat, (Bandung: Mizan Pustaka, 2007), 503.
} 
kesalahan oraang lain akan memperoleh kemuliaan karena ini adalah amal shaleh yang telah dicontohkan oleh Rasulullah saw.

Tokoh berikutnya yang membahas tentang kemaafan adalah al-Ghazali. AlGhazali memandang kata ghaffar berarti memperlihatkan keindahan dan menutupi keburukan. ${ }^{17}$ Selain kata menutup dari makna ghaffar yang dipakai untuk menutupi dosa juga dipakai untuk makna menutupi bisikan hati dan kehendak hati manusia yang buruk. Hal selanjutnya yang ditutup adalah menutupi pelanggaran yang dilakukan oleh manusia dan membalasnya dengan kebaikan-kebaikan. ${ }^{18}$ secara lebih sederhana yang dimaksudkan oleh al-Ghazali menutupi keburukan dan memperlihatkan keindahan adalah kemaafan akan memberikan keindahan, kebaikan pada pemberi maaf dan menghilangkan keburukan karena sesungguhnya menyimpan rasa dendam dan sakit hati akan menyakiti diri sendiri dan memberikan balasan atau hasil yang buruk bagi jiwa seseorang. Sehingga kemaafan sebenarnya memberikan kemanfaatan bagi kesehatan mental manusia.

Melihat dua pendapat tokoh di atas dapat dipetakan konsep berfikir keduanya tentang kemaafan. Jika Quraish Shihab beranggapan bahwa kemaafan hilang tak bersisa dan memiliki kelebihan maka al-Ghazali sebagai tokoh Islam klasik berpendapat bahwa kemaafan adalah menutupi keburukan dan memperlihatkan kebaikan. Jika ditarik benang merah keduanya memiliki hubungan yang jelas. Memberi maaf artinya menghilangkan rasa dendam dan menghilangkan kemarahan, kemampuan memberikan maaf dapat dilakukan jika seseorang memiliki kelebihan untuk mampu menghilangkan keburukan (dendam) pada dirinya. Sesungguhnya orang yang memberi maaf adalah mereka yang mampuberbuat baik terhadap orang yang telah berbuat jahat kepadanya. Sehingga kemaafan bermakna memperlihatkan keindahan karena memaafkan itu memberikan kedamaian sehingga hidup menjadi lebih indah.

\section{Kemaafan dalam Konsep Psikologi Positif}

Teori kemaafan dalam psikologi positif dapat ditemukan pemikiran beberapa tokohnya. Enright memberi devinisi pada forgiveness sebagai sikap memberikan maaf

\footnotetext{
${ }^{17}$ Ghazali, A. H. M. A. (1992). Al-Maqsad al-Asna fi s h arh Asma'Allah al-husna (The ninety-nine beautiful names of God). Translated by David B. Burrel and Nazer Daher. Cambridge: The Islamic Texts Society.

${ }^{18}$ Ghazali, A. H. M. A. (1992). Al-Maqsad al-Asna fi s h arh Asma’Allah al-husna ...,151.
} 
kepada seseorang yang telah berbuat tidak menyenangkan. Rasa sakit yang ditimbulkan karena perlakukan seseorang tidak disambut dengan balasan tetapi dibalas dengan kemurahan hati dan kasih sayang. ${ }^{19}$ Inilah makna forgiveness menurutnya. Sementara Hughes (1975) melihat forgiveness sebagai sebuah cara yang digunakan untuk memperbaiki harmoni sosial dalam sebuah lingkungan masyarakat ${ }^{20}$. Hal senada juga disampaikan oleh McCullought bahwa memaafkan dapat dijadikan motivasi untuk mengubah seseorang menjadi tidak membalas dendam dan meredakan dorongan untuk menjauhi atau menjaga jaga jarak dengan orang yang telah berbuat menyakitkan tersebut. ${ }^{21}$ Dengan memaafkan juga akan memunculkan dorongan untul berdamai dan berprilaku baik terhadap orang yang berbuat salah. Dengan demikian maksud dari forgiveness bagi mereka adalah upaya untuk menjaga hubungan baik dengan orang lain.

Memperhatikan beberapa definisi yang diberikan oleh tokoh tentang forgiveness tidak memiliki perbedaan yang significant. Philpot, $\mathrm{C}$ dalam buku yang sudah dikompilasi oleh American Psychology Association mengumpulkan beberapa pendapat para tokoh tentang forgiveness. Maka kesimpulan yang didapat menyatakan bahwa forgiveness terjadi ketika seseorang menyadari dirinya dalam posisi tersakiti dan ia merasa harusnya ia mendapat perlakuan yang lebih baik. Selanjutnya forgiveness ini merupakan proses perubahan emosi dalam bersikap terhadap orang yang telah menyakitinya. Mengenai pendapat bahwa forgiveness adalah perubahan atau peralihan dari emosi negatif ke emosi positif dalam memperlakukan terhadap pelaku dengan kasih sayang masih belum sepakat sejauh mana hal itu dapat terjadi. ${ }^{22}$ Untuk melihat sejauh mana para ahli melihat upaya berbuat baik terhadap pelaku dapat ditelusuri dengan tahapan yang telah mereka susun tentang forgiveness.

Para ahli memberi bermacam-macam cara dalam membuat tahapan untuk dapat sampai pada tahapan forgiveness ini oleh seseorang yang telah tersakiti. Dari beberapa tokoh yang mengkaji maka penulis hanya mengambil dua sampel saja dalam kerangka teori ini yaitu Enright (1998) dan Worthington. Enright dan Coyle mengembangkan

\footnotetext{
${ }^{19}$ Enright, R. D., Subkoviak, M. J., Wu, C. R., Gassin, E. A., Freedman, S., Olson, L. M., \& Sarinopoulos, I. (1995). Measuring interpersonal forgiveness in late adolescence and middle adulthood. Journal of adolescence, 18(6), 641.

${ }^{20}$ Hughes, M. (1975). Forgiveness. Analysis, 35(4), 113-117.

${ }^{21}$ McCullough, M. E., \& Witvliet, C. V. (2002). The psychology of forgiveness. Handbook of positive psychology, 2, 446-455.

${ }^{22}$ Philpot, C. R., \& Hornsey, M. J. (2011). Memory for intergroup apologies and its relationship with forgiveness. European Journal of Social Psychology, 41(1), 96-106.
} 
model tahapan forgiveness. Model ini meliputi aspek kognitif, afektif dan prilaku yang terjadi dalam proses forgiveness. Tahapan forgivenees dalam model ini dibagi menjadi empat fase. Fase pertama disebut Uncovering Phase ini merupakan proses pertama dimana seseorang perlu menyadari dan merasakan emosi negatif yang ia rasakan. Selanjutnya fase kedua adalah Desicion Phase adalah fase dimana penderita memiliki komitmen untuk memaafkan pelaku. ${ }^{23}$ Pada fase ini rasa dendam untuk membalas dendam dihilangkan.

Fase ketiga adalah fase Work Phase ini tahap dimana individu sudah dapat memaafkan pelaku dengan cara berempati. Individu menempatkan posisinya pada posisi pelaku yang pasti merasa tidak nyaman setelah berbuat salah. Pada fase ini individu memilih untuk menawarkan beberapa perbuatan yang baik. Fase keempat adalah Outcome/Deeping Phase dimana individu secara sadar merasa sembuh dan pulih dan telah memiliki emosi positif karena telah melakukan forgiveness. Demikian tahapan yang disusun oleh Elright terlihat sederhana dan seperti upaya terapi yang dilakukan oleh para teraphis dewasa ini dalam merelease perasaan-perasaan negatif dari masa lalu dengan membangkitkan kembali memori di alam bawah sadarnya.

Tokoh selanjutnya yang menyusun tahapan forgiveness adalah Worthington (1998). Teori yang digunakan disini dikenal sebagai the pyramid model to REACH forgiveness. Sekilas teori ini hampir sama dengan teorinya Enright hanya saja Worthington membagi proses menjadi lima tahapan. Yaitu Recall the hurt mengandung makna individu memanggil kembali rasa sakit akibat kejadian yang menyakitkannya. Empathize individu berusaha menemukan penyebab mengapa pelaku berbuat buruk terhadapnya dan memposisikan dirinya pada posisi pelaku. Alturistic gift individu berusaha mengingat bahwa dirinya juga pernah berbuat salah lalu orang lain memaafkannya dengan tulus, sehingga ia merasa layak juga untuk memaafkan orang lain.

Commit Publicly to forgive, tahap ini individu sudah memiliki komitmen untuk memaafkan keselahan seseorang dan berusaha untuk tidak mengingat kejadian itu dengan sengaja. Sambil pelan-pelan berupaya melupakannya. Hold on forgiveness, pada tahapan ini sebenarnya upaya untuk memaafkan dirasakan sudah sempurna namun

\footnotetext{
${ }^{23}$ Enright, R. D., \& Coyle, C. T. (1998). Researching the process model of forgiveness within psychological interventions. Dimensions of forgiveness: Psychological research and theological perspectives, 139-161.
} 
individu berusaha untuk dapat mempertahankannya. Individu berupaya merasakan dan memaknai keuntungan yang ia dapatkan setelah memaafkan pelaku yang telah menyakitinya. ${ }^{24}$ Untuk lebih jelasnya the pyramid model to REACH forgiveness dapat dilihat pada bagan piramid di bawah ini:
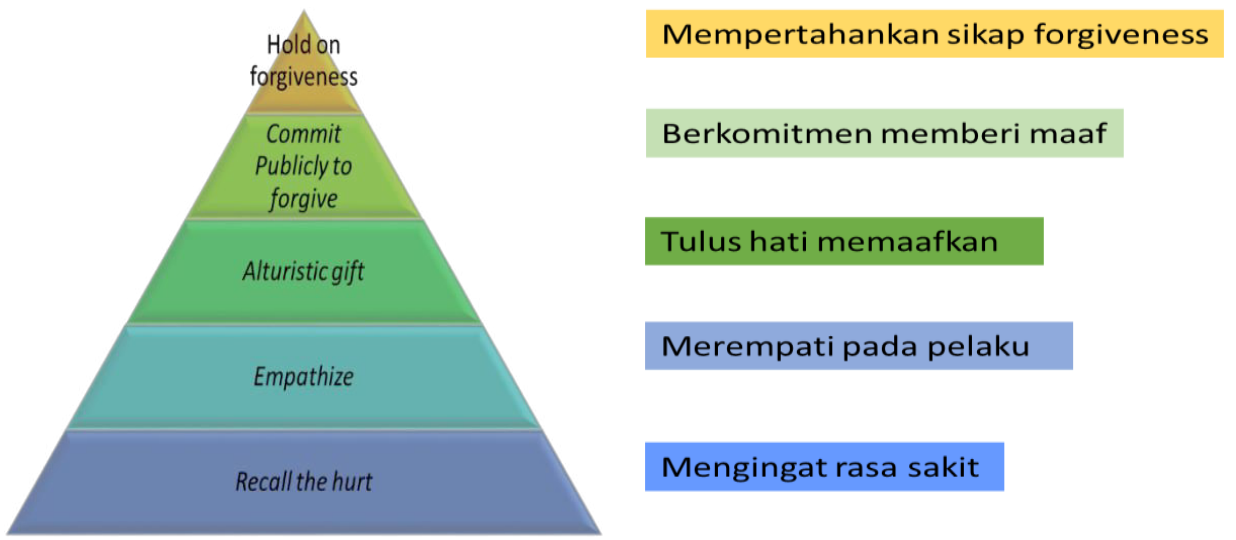

Gambar The pyramid model to REACH forgiveness

\section{Pendidikan Kedamaian di Era Digital}

Memperhatikan tahapan forgiveness dalm psikologi positif maka terlihat membutuhkan beberapa tahapan dan tahapan demi tahapan memerlukan waktu serta memerlukan tarapis yang dapat membantu seseorang menyembuhkan luka hatinya karena perlakuan negatif seseorang. Ini jelas sangat berbeda dengan ajaran dalam Islam dimana kemaafan dapat diberikan seketika dan tanpa perantara menusia yang lain. Hal ini disebabkan kemaafan yang diberikan kepada sesamanya memiliki ikatan dan hubungan yang kuat dengan nilai ilahiah. Seorang muslim apalagi mukmin akan mudah memberikan maaf kepada orang lain disebabkan sandaran yang kuat kepada Allah. Dimana dengan 3 domain islam yang dijelaskan di atas (aqidah/rukun Iman, syariah:/rukun Islam, dan Akhlak/rukun ihsan) seseorang memiliki sandaran yang kuat dengan Rabbnya. Sehingga kemaafan yang diberikan kepada orang yang menyakitinya bukan hanya pedulli dan nilai sosial pada orang lain tetapi terlebih dahulu karena cinta, takut dan harap pada Allah, Tuhan semesta.

Pertanyaan muncul apakah semua orang muslim memiliki kekuatan memaafkan yang sama kepada orang lain. Tentu saja tidak semua tergantung seberapa dekat ia

\footnotetext{
${ }^{24}$ Worthington Jr, E. L. (1998). The pyramid model of forgiveness: Some interdisciplinary speculations about unforgiveness and the promotion of forgiveness. Dimensions of forgiveness: Psychological research and theological perspectives, 107-137.
} 
Fitriah M. Suud, Pendidikan Kedamaian di Era Digital, Telaah Model Forgiveness dalam Psikologi Islam

dengan Tuhan dan seberapa tinggi derajat keimanan seseorang. Selanjutnya ini mengisyaratkan bahwa juga butuh usaha untuk seorang muslim agar dapat memiliki kemampuan untuk memberi maaf kepada orang lain. Maka di dalam islam banyak cara yang dapat digunakan untuk mendekatkan diri kepada Allah karena jika telah dekat dengan Allah hati seseorang akan tenang dan dengan mudah tidak mempersoalkan lagi urusan dengan manusia. Beberapa usaha memperbaiki suasana hati dan kedekatan diri dengan Allah dalam Islam dapat ditempuh dengan shalat, zikir, puasa dan ibadah lainnya. Terlihat dalam Islam setelah selesai bulan ramadhan dan memasuki bulan syawal yang disebut hari kemenangan atau idul fitri maka dengan mudah orang muslim memberikan maafkan dengan sesama mereka. Hal ini disebabkan hati mereka telah bersih dan semakin dekat dengan Tuhannya. Hal ini mestinya masih dapat terjaga dalam berbagai zaman dan waktu. Khususnya di era digital ini dimana banyak hal yang memudahkan manusia saling menyalahkan hingga sampai pada tahap saling menghilangkan nyawa.

Kemaafan sebagaimana di uraikan di dalam al-Qurán dan hadits Nabi di atas adalah sarana dan alat yang ampuh untuk menjadikan hidup kita tetap tenang dan damai. Namun ilmu akan sekedar menjadi ilmu jika hanya masih berada pada ranah pengetahuan saja. Merujuk pada pendidikan karakter yang di sampaikan oleh Thomas Lichona pendidikan karakter meliputi knowing, feeling dan doing. Hal yang sama juga dapat berlaku pada mendidik anak untuk dapat memaafkan orang lain dan juga memaafkan dirinya sendiri. Demikian juga halnya bagi orang dewasa upaya ini juga dapat dilakukan dengan melihat forgiveness dalam ranah aplikatif bukan hanya pada ranah ilmu yang normatif saja. Bicara tentang hal empiris tentang forgiveness kita dapat melihat bagaimana forgiveness dalam psikologi positif.

Penulis melihat usaha memberikan maaf kepada orang yang telah menyakiti butuh usaha yang berat. Baik ia sudah meminta maaf atau sebelum ia meminta maaf. Namun fungsi dari memberikn maaf kepada orang lain adalah memberikan ketenangan dalam jiwa manusia. Hal ini karena naluri manusia ingin selalu berbuat yang baik, bahwa manusia memiliki sisi sifat ilahiyah dalam jiwanya d isamping ia memiliki sifat insaniah. Nilai ilahiah akan lebih muncul ketika manusia melakukan kebaikan dan menghilangkan keburukan-keburukan dalam hati dirinya. Sehingga seseorang akan memperoleh ketenangan dan kebahagiaan ketika ia mampu memberikan maaf kepada 
orang lain. Selanjutnya apakah semua orang memiliki kemampuan yang sama dalam upaya memaafkan kesalahan orang lain terhadap dirinya. Sebelum melihat bagaimana meningkatkan kemampuan seseorang untuk dapat mudah memberikan maaf kepada orang lain, maka perlu melihat beberapa sebab yang mempengaruhi seseorang dalam memberikan kemaaan kepada yang lain.

Hal yang ikut mempengaruhi seseorang dalam memberikan maaf diantaranya adalah empati, penilaian terhadap orang lain, tingkat kelukaan seseorang, sifat karakteristik kepribadian seseorang, kualitas hubungan interpersonal, kualitas permintaan maaf, dan kondisi sosial kognitif seseorang. ${ }^{25}$ Berdasarkan faktor tersebut maka dapat diambil beberapa langkah solutif untuk melatih seseorang khususnya para pelajar atau anak didik untuk tumbuh menjadi individu pemaaf. Pertama adalah perlu menumbuhkan rasa empati seorang anak terhadap orang lain, membiasakan anak-anak ikut merasakan penderitaan orang lain. Secara riil para pendidik dapat membawa anakanak ke tempat dapat menyentuh kepekaan sosialnya, seperti melakukan school visit ke panti asuhan dan sekolah luar biasa. Selain itu juga dapat mengaktifkan program berbagi, setiap bulan sekali anak-anak diajak untuk berbagi pada masyarakat kurang mampu dan yang membutuhkan bantuan.

Kedua, membiasakan anak-anak berfikir positif, memberikan dan menanamkan nilai husnul zhan pada orang lain. Bahwa setiap orang sebenarnya ingin berbuat baik sama halnya denga dirinya dan bahwa setiap perbuatan baik selalu ada hikmah dan balasan kebaikan. Metode yang dapat digunakan adalah melalui pemberian tugas paper untuk siswa remaja dan untuk siswa kelas dasar bisa dengan cara bercerita dan eksploring. Ketiga, hubungan interpesrsonal seseorang dapat ditingkatkan dengan mengajak siswa sering berdiskusi dan berinteraksi dengan orang lain. Ini merupakan tantangan yang berat di era digital karena kebanyakan anak dan bahkan orang dewasa sibuk dengan gadgetnya masing-masing. Mereka tumbuh menjadi seorang yang individualis dan lebih introvert. Tugas pendidik adalah menghadirkan berbagai kegiatan yang membuat mereka aktif dan ikut terlibat dalam kegiatan bersama-sama. Memberikan tugas kerja kelompok dan berdiskusi di dalam kelompok dan di luar kelompok merupakan salah satu cara yang dapat ditempuh oleh guru.

\footnotetext{
${ }^{25}$ Enright, R. D., \& Coyle, C. T. (1998). Researching the process model of forgiveness within psychological interventions. Dimensions of forgiveness: Psychological research and theological perspectives, 139-161.
} 
Fitriah M. Suud, Pendidikan Kedamaian di Era Digital, Telaah Model Forgiveness dalam Psikologi Islam

Islam mengajarkan jika seseorang marah maka is segera mengambil wudhu lalu shalat, jika sedang duduk maka berdiri jika sedang berdiri maka ia segera duduk. Artinya bergerak dari kondisi sebelumnya. Hal ini memberikan sinyal bahwa seseorang dalam kondisi marah perlu mencari susasana baru, setelah bersentuhan dengan hal baru ia akan mudah melupakan luka karena kejadian tersebut. Walaupun tidak mungkin bagi otak manusia melupakan setiap kejadian secara keseluruhan yang telah melekat dalam memorinya, namun ia dapat menurunkan tingkat rasa sakit yang dia alami sehingga ia pun mudah untuk memaafkannya. Islam juga mengajarkan banyak beristighfar untuk menyejukkan hati. Sehingga hal ini dapat diajarkan dan dibiasakan kepada anak-anak untuk sering beristghfar dalam banyak hal.

\section{Penutup}

Zaman digital adalah zaman tanpa batas untuk arus informasi yang lintas agama dan negara. Banyak keuntungan dan hal positif dari era digital ini. Banyak hal yang susah menjadi mudah dan yang lama menjadi cepat semua dapat dilakukan dengan mudah dengan bantuan peralatan teknologi yang semakin canggih. Menanggapi banyak persoalan yang negatif dari perubahan zaman ini Islam tetap memiliki obat untuk penawar perubahan zaman. Kemaafan merupakan salah satu cara untuk memberikan kedamaian dalam kehidupan seseorang. Kemaafan ini berlaku untuk diri sendiri dan juga untuk orang lain. Memaafkan orang lain akan membuat hidup lebih tenang dan damai sementara memaafkan diri sendiri membuat hidup menjadi qanaah dan tawadhu'.

Ajaran islam dalam pendidikannya perlu menjadikan kemaafan bagian yang tersampaikan kepada siswa baik secara tersurat maupun yang tersirat dalam prilaku yang dibudayakan di lembaga pendidikan. Kehidupan Nabi Muhammad saw hendaknya dapat dijadikan cerita kepada para siswa hingga dapat menyentuh ranah afektif atau domain feeling dari pada peserta. Sementara dalam upaya mempraktekkan kemaafan dalam dilalui dengan beberapa langkah yaitu mengingat rasa sakit yang kita miliki kemudian berempati pada pelaku bahwa ia juga merasakan rasa sakit yang kita miliki karena sesungguhnya setiap jiwa mendambakan ketenangan dan kedamaian dalam hidupnya. Langkah ketiga adalah berusaha memaafkan kesalahannya, selanjutnya tetap berkomitmen memberikan kemaafan dan terakhir bertahan untuk memiliki sifat kemaafan kepada siapapun. Islam sebagai agama rahmatan lil alamin dengan Rasulullah sebagai suri teladan merupakan kesempurnaan dari ajaran praktek dalam kehidupan. Hal 
ini juga terkait bahwa Islam mengajarkan ridha ikhlas hati pada apapun yang berlaku dalam hidup serta yakin bahwa semua kita akan kembali kepada Allah SWT dengan membawa pertanggungjawaban atas segala yang telah kita lakukan dunia. Maka forgiveness dalam bingkai Islam merupakan solusi untuk mendapatkan ketenangan hidup di dunia dan bahagia di akhirat. 
Fitriah M. Suud, Pendidikan Kedamaian di Era Digital, Telaah Model Forgiveness dalam Psikologi Islam

\section{Daftar Pustaka}

1992. Al-Maqsad al-Asna fi s h arh Asma'Allah al-husna (The ninety-nine

beautiful names of God). Translated by David B. Burrel and Nazer Daher. Cambridge: The Islamic Texts Society.

----------. 2007. Membumikan al-Qur'an fungsi dan Peran wahyu dalam masyarakat,

Bandung: Mizan.

-. 1994.Lentera Hati Bandung: Mizan,

2003. Tafsir Al-Mishbah: Pesan, Kesan, dan Keserasian al-Qur'an, Jakarta:

Lentera Hati.

-1996. Wawasan al-Qur'an, Bandung: Mizan.

Abdul Mun "eim Al-Hasyimi. 2009. Akhlak Rasul Menurut Bukhari dan Muslim. Jakarta: Gema Insani. Cet I.

Abdullah, M. A. 1996. Studi Agama: Normativitas atau Historisitas. Yogyakarta: Pustaka Pelajar.

Al-Ghazâlî, Abu Hamid Muhammad. 1980. Ihyâ' 'Ulûm Al-Dîn. Beirut : Dâr al-Fikr, Juz III.

Ali, S. 2017. "Forgiveness Model Profetik dalam Bandingan Struktural Teori Konflik". Analisis: Jurnal Studi Keislaman. Vol 14. No.1.

Al-Mabuk, R. H., Enright, R. D., \& Cardis, P. A. 1995. Forgiveness Education With Parentally Love Deprived Late Adolescents. Journal of Moral Education.

Al-Mahalli, I. J. 2009. Tafsir Jalalain. Jilid 1. B. A. Bakar, Penerj. Bandung: Sinar Baru Al-Gesindo.

Al-Qur'an dan Terjemahan

Cholidi, "Maghfirah,” . 2008. dalam M. Quraish Shihab,et al.ed..Ensiklopedia AlQur'an: Kajian Kosa Kata, vol. III. Jakarta: Lentera Hati.

Enright, R. D., \& Coyle, C. T. 1998. Researching the Process Model Of Forgiveness Within Psychological Interventions. Dimensions of forgiveness: Psychological research and theological perspectives.

Enright, R. D., Subkoviak, M. J., Wu, C. R., Gassin, E. A., Freedman, S., Olson, L. M., \& Sarinopoulos, I. 1995. Measuring interpersonal forgiveness in late adolescence and middle adulthood. Journal of adolescence, Vol.18. No.6. .Forgiveness as human strength: Theory, Measurement, And Links To Well-Being. 
Freedman, S., Enright, R. D., \& Knutson, J. 2005. A progress report on the process model of forgiveness. Handbook of Forgiveness.

Gerlach, T. M., Allemand, M., Agroskin, D., \& Denissen, J. J. 2012. Justice sensitivity and forgiveness in close interpersonal relationships: The mediating role of mistrustful, legitimizing, and prorelationship cognitions. Journal Of Personality.

Ghuzairoh, T. 2015. Perbedaan forgiveness ditinjau dari jenis kelamin pada Budaya Jawa. Doctoral dissertation, Universitas Islam Negeri Maulana Malik Ibrahim.

Hughes, M. 1975. Forgiveness. Analysis.

Klaus Krippendorff. 1991. Content Analysis; Introduction to Its Theory and Methodology. Diterjemahkan oleh Farid Wajidi. Jakarta: Rajawali Press

Kutubus Tis'ah. Kitab Hadits Digital.

Macaskill, A., Maltby, J., \& Day, L. 2002. Forgiveness of self and others and emotional empathy. The Journal of social psychology. Vol. 145. No 5.

Mahally, J., \& al-Suyuthy, J. A. R. Tafsir al-Jalalain. Cairo: Mathba'ah al-Sya'b, t. th, Al-Mahalli, I. J. 2009. Tafsir Jalalain Jilid 1. B. A. Bakar, Penerj. Bandung: Sinar Baru al-Gesindo.

McCullough, M E., Root, Lindsey M., Cohen, Adam D. 2006. Writing About the Benefits of an Interpersonal Transgression Facilitates Forgiveness. Journal of Consulting and Clinical Psychology. Vol. 74. No. 4.

McCullough, M. E. 2000. Forgiveness as human strength: Theory, measurement, and links to well-being. Journal of Social and Clinical Psychology. Vol. 19. No.1.

McCullough, M. E., \& Witvliet, C. V. 2002. The psychology of forgiveness. Handbook of positive psychology.

McCullough, M. E., Fincham, F. D., \& Tsang, J. A. 2003. Forgiveness, forbearance, and time: the temporal unfolding of transgression-related interpersonal motivations. Journal of personality and social psychology.

McCullough, Michael E., Worthington, Everentt L., Rachal, Kenneth. 1997. Interpersonal Forgiving in Close Relationships. Journal of Personality and Social Psychology.

Moleong, L.J. 1996. Metodologi Penelitian Kualitatif. Bandung: Penerbit PT. Remaja Rosdakarya. 
Fitriah M. Suud, Pendidikan Kedamaian di Era Digital, Telaah Model Forgiveness dalam Psikologi Islam

Fuas Ábdul Baqi, Muhammad 1428H/2007M Mu’jam Mufahras li Alfazh Al-Qurán alKarim, al:Qahirah, Dar al Hadits,.

Syafiei Antonio. 2009. Muhammad Asma"ul Husna For Success in Business \& Life Jakarta: Tazkia Publishing.

Mujib, A. 2012. Konsep Pendidikan Karakter Berbasis Psikologi Islam. Jakarta: Pustaka Pelajar.

Mujib, A. 2017. Pengembangan Psikologi Islam Melalui Pendekatan Studi Islam. Jurnal Psikologi Islam. Vol.4. No. 8.

Park, J. H., Enright, R. D., Essex, M. J., Zahn-Waxler, C., \& Klatt, J. S. 2013. Forgiveness intervention for female South Korean adolescent aggressive victims. Journal of Applied Developmental Psychology. Vol. 34. No. 6.

Philpot, C. R., \& Hornsey, M. J. 2011. Memory for intergroup apologies and its relationship with forgiveness. European Journal of Social Psychology.Vol. 41. No. 1.

Shihab, Quraish, 2004. Menyingkap Tabir Ilahi. Jakarta: Penerbit Lentera Hati.

Rahmandani, A., \& Subandi, M. A. 2017. Pengaruh Terapi Pemaafan dalam Meningkatkan Penerimaan Diri Penderita Kanker Payudara. JIP: Jurnal Intervensi Psikologi. Vol. 2. No. 2.

Setiyana, V. Y. 2013. Forgiveness dan stres kerja terhadap perawat. Jurnal ilmiah Psikologi Terapan. Vol. 23. No. 3.

Snyder, C. R., \& Lopez, S. J. 2009. Oxford handbook of positive psychology. Oxford University Press, USA.

Tangney, J. P., Boone, A. L., \& Dearing, R. 2005. Forgiving the self: Conceptual issues and empirical findings. Handbook of forgiveness.

Walton, E. 2005. Therapeutic forgiveness: Developing a model for empowering victims of sexual abuse. Clinical Social Work Journal, Vol. 33. No. 2.

Worthington Jr, E. L. 1998. The pyramid model of forgiveness: Some interdisciplinary speculations about unforgiveness and the promotion of forgiveness. Dimensions of forgiveness: Psychological research and theological perspectives.

Worthington Jr, E. L. 2006. Forgiveness and reconciliation: Theory and application. Routledge. 
FIKROTUNA: Jurnal Pendidikan dan Manajemen Islam Volume 7, Nomor 1, Juli 2018

Worthington, E. L., \& Scherer, M. 2004. Forgiveness is an emotion-focused coping strategy that can reduce health risks and promote health resilience: Theory, review, and hypotheses. Psychology \& Health. 